\title{
Studies on Use of Sand-Bentonite and Sand-Fly Ash Mixtures as Prospective Liner Materials to Retain Iron and Copper in Aqueous Solutions
}

\author{
Shankara (Corresponding author) \\ Assistant Professor, Dept. of Civil Engineering \\ Amrita School of Engineering, Bangalore-560 035, India \\ E-mail: bcreative_shank@yahoo.com \\ Maya Naik \\ Professor, Dept. of Civil Engineering \\ BMS College of Engineering, Bull Temple Road, Bangalore-560 019, India \\ E-mail: snmcivbmsce@gmail.com \\ P.V. Sivapullaiah \\ Professor, Dept. of Civil Engineering \\ Indian Institute of Science, Bangalore 560 012, India \\ E-mail: siva@civil.iisc.ernet.in
}

Received: July 16, 2012 Accepted: September 16, 2012

doi:10.5296/emsd.v1i2.2301ＵRL: http://dx.doi.org/10.5296/emsd.v1i2.2301

\begin{abstract}
The main aim of the present work has been to understand the retention behavior of metal ions of copper and iron by mixtures of sand bentonite and sand fly ash in the context of their use as liners for waste disposal facilities. Fine sand containing high silica, bentonite, fly ash mixtures have been used to study the sorption behavior. Batch adsorption studies were carried out to estimate the adsorption capacities of two different soil mixtures namely SandBentonite (SB) and Sand Fly ash (SF). It was found that at different Soil to Liquid ratios (S/L) sand bentonite mixture with $20 \%$ bentonite sorbs the higher amount of copper whereas sand
\end{abstract}


fly ash mixture with $10 \%$ fly ash sorbs the higher amount of iron. Similarly at different initial concentration $20 \%$ sand bentonite mixture sorbs the higher amount of copper whereas $10 \%$ sand bentonite mixture sorbs the higher amount of iron. Sorption/adsorption isotherms were also established for the experimental data, which indicate that adsorption of heavy metal ions on to SB and SF were favorable.

Keywords: Retention, Heavy metal, Sorption, Batch equilibrium, Fly ash, Bentonite

\section{Introduction}

Heavy metals are discharged from mining and various other industries such as electroplating, metal finishing, textile, storage batteries, etc. Some of the heavy metals are toxic even at very low concentration and pose serious environmental problems and are dangerous to human health and ecosystem. Many cities in developing countries like India are facing serious problems of disposing solid, liquid and hazardous waste generated by various industries. Solid waste landfills used for disposal of industrial wastes constitute a potential threat to the ground water. Soil liners have been widely used to control and contain toxic and hazardous materials and minimize soil and ground water contamination. Heavy metals may chemically or physically interact with the natural compounds, which changes their forms of existence in the environment and react with certain species, change their oxidation states and precipitates. Heavy metals like iron, copper etc, may also be bound or sorbed by natural substances present in soils which may increase or decrease their mobility (Dube, Zbytniewski, Kowalkowski, Cukrowska \& Buszewski, 2001). Liners are frequently constructed with natural materials serving as primary barriers. Current EPA guidance allows single and double liners of compacted clays across sections to be installed at waste disposal sites. Soil liners are preferred because of their low cost, large leachate attenuation capacity and resistance to damage and puncture (Mohammed \& Naik, 2011).

Soils comprising high clay content are most commonly used and EPA guidelines requires that soil liners must be built such that hydraulic conductivity is equal to or less than $1 \times 10^{-7} \mathrm{~cm} / \mathrm{sec}$. In addition, the compatibility of a clay liner to a specific contaminant depends on two factors, the ability of the clay liner to resist any increase in hydraulic conductivity due to the contaminant and its capacity to retard the migration of contaminants through sorption. A number of studies on hydraulic conductivity have been carried out but sorption behavior of compacted clay soils has not been carried out extensively for Indian scenario. Heavy metals, such as copper and iron are commonly found in several kinds of waste and hence in landfill leachates (Mor \& Ravindra, 2006). The leachates generated may contain many toxic metal ions. Adsorption of soluble metallic species by clays, oxides and other colloidal matters appears to be an important means of controlling the trace soluble metal concentrations in the heterogeneous system. Bentonite containing good amount of clay content is considered to be an adsorbent for the removal of various heavy metal ions such as Cadmium, Lead Copper iron, manganese and nickel. Conventional technologies for the removal of heavy metal ions such as chemical precipitation, electrolysis, ion exchange and reverse osmosis are often neither effective nor economical. Among the physico-chemical treatment process, adsorption is highly effective, cheap and easy to adopt. Adsorption is proven to be a successful method 
for removal of heavy metals from landfill leachate. (Tahir \& Naseem, 2004) The objective of the present study is to investigate adsorption characteristics for removal of heavy metal ions such as copper and iron from an aqueous solution by the use of sand fly ash and sand bentonite mixtures. Also addition of additives like lime and cement in low percentages to soil to enhance their retention capacities has been considered. A brief description of studies carried out on adsorption of copper and iron has been presented.

Copper: Copper is retained in soils through exchange and specific adsorption mechanisms, and also copper precipitates are unstable. This may not be the case in waste-soil systems and precipitation may be an important mechanism of retention. $\mathrm{Cu}$ is generally adsorbed to a greater extent by soils and soil constituents than other metals found in the waste matrix. Copper, however, has a high affinity for soluble organic ligands and the formation of the complexes may greatly increase $\mathrm{Cu}$ mobility in soils. It has been found that copper reaches equilibrium in a short period, and there is not much change with time. (Cavallaro\& McBride,

1978; Mohammed, Naik, \& Tanveeruddin, 2009). Studies have shown that, copper adsorption occurs not only by ion exchange cations, but also by specific adsorption, which can be described by surface complexation model which define a reaction between functional surface group and copper ions. (Eren \& Afsin, 2008). Kinetic studies reveal that removal of $\mathrm{Cu}^{2+}$ was highly dependent on concentration and the increases with increasing, $\mathrm{Cu}^{2+}$ concentration. This was attributed due to the increase of metal ions for sorption on sorbent and the competition is less at lower initial concentration as sufficient adsorption sites are available for sorption of $\mathrm{Cu}^{2+}$. Conversely the number of $\mathrm{Cu}^{2+}$ ions at higher concentration is relatively more compared to the available adsorption sites. (Mohammed \& Naik, 2010)

Iron: It is reported that iron (Fe) is the fourth-most abundant element in Earth's crust, next to oxygen, silicon, and aluminum. Iron-bearing clays are ubiquitous in nature. It's abundantly present in all clays and clay minerals and an intimate part of many processes occurring in natural ecosystems (Stucki, 1988). Iron is generally considered as harmless, though sometimes annoying, element present in public and private water supplies. High concentrations of dissolved iron results in poor tasting, unattractive water that stains both plumbing fixtures and clothing. Concentrations of iron as low as 0.3 milligrams per liter ( $\mathrm{mg} / \mathrm{L}$ ) will deposit reddish-brown stains on fixtures, utensils, and clothing, all of which can be difficult to remove. Ferric iron deposits within corroded pipes can break free and generate rusty tap water. Iron bacteria gives water a disagreeable taste and causes yellow stains on laundry. This bacterium can also clog water systems, plug filters, or envelop pump screens, resulting in expensive repairs.

Iron removal $\mathrm{Fe}$ (II) from aqueous solution has been traditionally carried out by crystallization or oxidation of Fe (II) to Fe (III) and then chemical precipitation. Effective removal of iron Fe (II) from galvanized pipe manufacturing industrial waste water has been carried out using bentonite using as an adsorbent after optimization of adsorption conditions. (Tahir \& Naseem, 2004).

In the present investigation an attempt has been made to study the adsorption behavior of copper and iron by sand bentonite and sand fly ash mixtures at different soil to liquid ratios (constant concentration) and with varying initial concentration of copper and iron solution 
(with soil to liquid ratio constant).

\section{Materials}

Foundry Sand: A foundry sand which Consists primarily of clean, uniformly graded, high-quality silica sand or lake sand that is bonded to form molds for ferrous (iron and steel) and nonferrous (copper, aluminum, brass) metal castings. The automotive industry and its parts suppliers are the major generators of foundry sand.. Silica fine sand was collected from foundry lab of Amrita school of engineering, Bangalore, supplied by Arun Alloy Cast Company.”

Fly ash used: A fly ash of class "F" category procured from Raichur Thermal Power Station (RTPS), in Karnataka, India, called Raichur Fly ash (RFA), used in the present study. The fly ash used was grey in color, the physical properties and the chemical composition of the fly ash are given in Table 1and Table 2.

Bentonite used: Bentonite is a natural clay mineral and is found in many places of the world it belongs to 2:1 clay family. The basic structure is composed of two tetrahedrally coordinated sheets of silicon ions surrounding by a sandwiched octahedrally coordinated sheet of aluminum ions. The isomorphs substitution of $\mathrm{Al}^{3+}$ for $\mathrm{Si}^{4+}$ in the tetrahedral layer and $\mathrm{mg}^{2+}$ or $\mathrm{Zn}^{2+}$ for $\mathrm{Al}^{3+}$ in the octahedral layer results in a net negative surface charge on the clay. Compared with other clay types, it has excellent sorption properties and possesses sorption sites available within its interlayer space as well as on the outer edges. Bentonite procured from Kolar region of Karnataka was used in the present study and typical analysis is presented in table 3.

Chemicals used: Synthetic heavy metals were prepared by dissolving a known quantity of ammonium ferrous sulphate in distilled water to represent iron; similarly cupric sulphate crystals were dissolved in distilled water to represent copper. The chemicals used were supplied by Qualigens Company of Analytical Grade (AR).

\section{Sorption Studies}

The sorption of copper and iron for sand bentonite and sand fly ash mixtures were established based on batch equilibrium test and at different soil to liquid ratio and at varying initial concentration of metal solution.

Batch Adsorption Tests: In this study batch adsorption tests were done according to ASTM D 4646-87(reapproved 2001). This test method is meant to allow for a rapid (24 h) index of a geomedia's sorption affinity for given chemicals or leachate constituents. The 24-h duration is used to make the test convenient and also to minimize microbial degradation which may be a problem in lengthened procedures. Due to this time constraint, the final (24-h) concentration should not be confused with that of an equilibrium or steady-state concentration. The 24-h time limit will be sufficient to reach the steady-state.

About 5 to $70 \mathrm{~g}$ (oven-dried basis) of the weighed air-dried sample was placed into the appropriate container. The samples were weighed to a minimum of three significant figures. Samples with S/L ratios of 1:10, 1:20, 1:30, 1:40 and 1:100 was prepared and then placed 
on shaker. It was agitated continuously for $24 \pm 0.5 \mathrm{~h}$ at $29 \pm 2 \mathrm{r} / \mathrm{min}$ at room temperature (22 $\pm 5^{\circ} \mathrm{C}$ ), and then $1000 \mathrm{mg} / \mathrm{l}$ of contaminant was added proportionally to all samples so that we get same concentration in all the containers and again shaken for 24 hours. The samples were then removed, filtered. After a clear solution has been obtained, an aliquot was placed in an appropriate container, and analyzed or stored in a refrigerator at $4 \pm 2{ }^{\circ} \mathrm{C}$ until the analysis. For different initial concentration and for different $\mathrm{pH}$ tests the procedure will be the same but maintaining a constant $\mathrm{S} / \mathrm{L}$ ratio of $1: 20$ in all the containers.

Batch adsorption tests at different dilution ratios: Samples with S/L ratios (soil to liquid ratio) of 1:10, 1:20, 1:30, 1:40, 1:100, were taken and shaken for 24 hours. Then, $1000 \mathrm{mg} / \mathrm{l}$ of contaminant was added to all samples and again shaken for 24 hours. (This doubles the soil to liquid ratio to $1: 20,1: 40,1: 60,1: 80,1: 200$, and the concentration of contaminant in this solution will be reduced to $500 \mathrm{mg} / \mathrm{l}$.) The samples were then removed, filtered through whatman filter paper no.42 and the filtered liquid was analyzed for its concentration.

Batch adsorption tests at different initial concentrations of contaminants: 5grams of adsorbent was taken in approximately $100 \mathrm{ml}$ of distilled water to maintain a S/L (soil to liquid) ratio of $1: 20$ and shaking for 24 hours, then $1 \mathrm{ml}, 2.5 \mathrm{ml}$ and $5 \mathrm{ml}$ of $1000 \mathrm{mg} / \mathrm{l}$ contaminant was added to three samples separately to get $10 \mathrm{mg} / \mathrm{l}, 25 \mathrm{mg} / \mathrm{l}$ and 50mg/l respectively, similarly $1 \mathrm{ml}, 2.5 \mathrm{ml}$ and $5 \mathrm{ml}$ of $10,000 \mathrm{mg} / \mathrm{l}$ contaminant was added to another three samples separately to get $100 \mathrm{mg} / \mathrm{l}, 250 \mathrm{mg} / \mathrm{l}$ and $500 \mathrm{mg} / \mathrm{l}$ respectively and then all the samples were subjected to shaking for another 24 hours. The samples were then removed, filtered and the filtered liquid was analyzed for its concentration.

Atomic Absorption spectrophotometer supplied by Chemito AA203 model has been used to determine concentrations of Iron and Copper. The analytical calibration was accomplished with aqueous solutions. Fresh calibrations were made each time before analysis. The operating wavelength parameter for copper was $324.8 \mathrm{~nm}$ for concentration 2 to $8 \mathrm{ppm}$ and for Iron $248.3 \mathrm{~nm}$ for 2 to $10 \mathrm{ppm}$. Standard graphs were plotted, the trends in the graphs matched with the standard curves given in literature.

\section{Results and Discussion}

The results of the sorptionj studies are presented in the following sections.

\subsection{Retention of metal ions at different soil to liquid ratios}

Fig. 1 shows adsorption of copper by sand bentonite mixture (SB) with 5,10,20\% of bentonite and sand fly ash mixture (SF) with $10,20,50 \%$ of fly ash. It can be seen that soprption of $\mathrm{Cu}$ on any SB and SF mixtures by soil is almost same for any soil to liquid ratio up to 80. With the increase in percentage bentonite, sorption also increased but the variation is uniform and for $20 \%$ bentonite the sorption is at about $45 \mathrm{mg} / \mathrm{g}$. whereas in case of fly ash mixtures it is observed that with increase in percentage age of fly ash, amount of sorption also increases and is proportional to dilution ratio. It was found that at $20 \%$ sand bentonite mixture, the amount of sorption was about $45 \mathrm{mg} / \mathrm{g}$ followed by $50 \%$ sand bentonite mixture. The sorption of copper is of the order $20 \%$ Bentonite $>50 \%$ fly ash $>20 \%$ fly ash $>10 \%$ bentonite $>5 \%$ bentonite $>10 \%$ fly ash. In general, with increase in solid liquid ratio sorption increases 
proportionately, but amount of sorption is is not uniform in all the cases.The reason for the maximum adsorption of $\mathrm{Cu}$ on bentonite is mainly due to the fact that it has got exccellent sorption properties and possesses sorption sites available with in its interlayer space as well as outer surface and edges. Adsorption of $\mathrm{Cu}$ on to bentonite appears to involve two distinct mechanisms namely, ion exchange reaction and formation of complexes with the surface hydroxyl groups. Hence the amount of sorption is more in case of sand bentonite mixtures when compared to sand fly ash mixtures.

Fig. 2 shows adsorption of iron by sand bentonite mixture (SB) with 5,10,20\% of bentonite and sand fly ash mixture (SF) with $10,20,50 \%$ of fly ash. It can be seen that soprption of amount of Fe on any SB and SF mixtures with soil to liquid ratio up to 60, is almost same. With the increase in percentage bentonite, sorption also increased but the variation is not uniform in most of the cases. With $10 \%$ and $20 \%$ bentonite the variation is almost the same and more than that of $5 \%$ bentonite. In case of fly ash mixtures with increase in percentage of Fly ash sorption also increased but the variation is inversely proportional to dilution ratio. It can be seen that $10 \%$ sand fly ash mixture has given the highest sorption followed by $10 \%$ bentonite mixture. The sorption of iron is of the order $10 \%$ fly ash $>20 \%$ fly ash $>10 \%$ bentonite $>20 \%$ bentonite $>50 \%$ fly ash $>5 \%$ bentonite.In general with increase in solid liquid ratio sorption also increases but amount of sorption is not uniform for all the percentages of sand fly ash and sand bentonite mixtures. Also it was found that with increase in percentage of fly ash sorption has decreased beyond $\mathrm{S} / \mathrm{L}$ ratio of 80 .The reason might be due to the fact that fly ash already contains excess amount of iron and alumina as its main constituents, but with futhear addition of iron in the form of solution decreases sorption. It is evident that presence of lower amount of fly ash in the mixture reduces the total concentration of iron in the mixture and hence sorption increases at lower percentage of fly ash as there are more number of sorption sites are available. It can be concluded that the effective sorption of iron has occurred at $10 \%$ fly ash when compare to $20 \%$ and $50 \%$ fly ash.

\subsection{Retention of metal ions at different initial concentrations}

Adsorption of copper by sand bentonite mixture (SB) with 5,10,20\% of bentonite and sand fly ash mixture (SF) with $10,20,50 \%$ of fly ash has been shown in fig.3. It can be seen that amount of soprption of Cu on any SB and SF mixtures with initial concentration of copper, is almost same up to almost 100mg/l of Cu solution. However, beyond 100mg/l of Cu solution , the sorption of SB mixture is higher than sorption of SF mixture,also the sorption of SB mixture increases with bentonite content the sorption on fly ash also increases with increases in \% of fly ash in mixture. This shows that the sorption of bentonite which is essentially due to higher CEC value of the bentonite, and the sorption of fly ash not by CEC, only by precipitation.

Here again, in the Fig. 4 the effect of type of mixture is not seen up to initial concentration of Fe up to about $50 \mathrm{ppm}$. However, the differences are seen at higher concentration exceeding $50 \mathrm{ppm}$.Even in the case of iron the sorption of SB mixture higher than that of SF mixture at the same quantity of bentonite and fly ash. For both bentonite $20 \%$ and fly ash $50 \%$ mixtures 


\section{I Macrothink}

the sorption of Fe is seems to decrease as the initial concentration is increased to 250ppm. As in the case of retention by bentonite which is due to CEC value is more effective than in case of FA which can retain heavy metal only by precipitation. The lowest adsorption in case of $50 \%$ fly ash due to already existing iron content in fly ash and subsequently reached equilibrium conditions.

\subsection{Comparative performance of metal ions for retention on different mixtures:}

Fig. 5 and Fig. 6 show comparison of amount metal sorbed for sand fly ash and sand bentonite mixtures at different solid to liquid ratios and at different initial concentrations. In both the cases the behavior of these mixtures was similar. It was found that sand bentonite mixture with $20 \%$ bentonite sorbs higher amount of copper to a magnitude of $45 \mathrm{mg} / \mathrm{g}$ of soil mixture and sand fly ash mixture with $10 \%$ fly ash sorbs higher amount of iron with a magnitude of about $20 \mathrm{mg} / \mathrm{g}$ of soil mixture. It can be inferred that among all the mixtures studied, copper adsorbed more than iron, this was because copper gets adsorbed by ion exchange, and also due to specific adsorption which can be described by surface complexation reactions between functional surface groups and copper ions. Also bentonite has a higher CEC value, which helps sorption of copper through formation of organic ligands, precipitation and complexation reactions. It is also reported that copper has a reduction potential of $+0.34 \mathrm{~V}$, whereas iron has a reduction potential of $-0.44 \mathrm{~V}$. This means that copper is a better reducing agent when compared to iron and can get reduced to form a stable product. Hence the sorption of copper is much higher than iron.

\section{Conclusions}

Based on detailed studies carried on the adsorption of copper and iron at different initial concentrations and at different soil: liquid ratios by fine sand with bentonite and fly ash the following important r conclusions are drawn.

1. The adsorption of heavy metal ions by sand bentonite and sand fly ash mixtures has been found to increase with increase in initial concentration and also with soil : liquid ratios.

2. It was found that sand with bentonite sorbs copper better than sand with fly ash at different soil to liquid ratios.

3. Similarly sand fly ash mixture sorbs iron better than sand bentonite mixture at different initial concentrations.

\section{References}

Cavallaro, N., \& McBride, M. B. (1978). Copper and cadmium adsorption characteristics of selected acid and calcareous soils. Soil Sci. Soc. Am. J., 42, 550-556. http://dx.doi.org/10.2136/sssaj1978.03615995004200040003x

Dube, A., Zbytniewski, R., Kowalkowski, T., Cukrowska, E., \& Buszewski, B. (2001). Adsorption and migration of heavy metals in soils. J. of environmental studies, 10(1), 1-10. 


\section{Macrothink}

Eren, E., \& Afsin, B. (2008). An investigation of Cu (II) adsorption by raw and acid activated bentonite: A combined potentiometric thermodynamic, XRD, IR, DTA study. Journal of hazardous material, 151, 682-691. http://dx.doi.org/10.1016/j.jhazmat.2007.06.040

Mohammed, S. A. S., \& Naik, M. (2010). Adsorption characteristics of metals in aqueous solution by local materials with additives as liners for waste containment facilities. J. Water Environ. Technol., 8(1), 29-50. http://dx.doi.org/10.2965/jwet.2010.29

Mohammed, S. A. S., \& Naik, M. (2011). Potential use of black cotton soil with additives as a liner material to retain zinc: Isotherm and kinetic studies. Int. J. Ecol. Dev., 19(11), 15-29.

Mohammed, S. A. S., Naik, M., \& Tanveeruddin, S. (2009). Influence of additives on the retention of metal ions in a soil of Bangalore, India. Ambiente Agua-An Interdisciplin. $J$. Appl. Sci., 4(1), 20-36. http://dx.doi.org/10.4136/ambi-agua.71

Mor, S., Ravindra, K., Visscher, A. D., Dahiya, R. P., \& Chandra, A., (2006). Municipal solid waste characterization and its assessment for potential methane generation: a case study. Science of the Total Environment, 371(1), 1-10. http://dx.doi.org/10.1016/j.scitotenv.2006.04.014

Stucki, J. W. (1988). Iron in smectites. In: Stucki, J.W., Goodman, B.A., Schwertmann, U. (Eds.), Iron in Soils and Clay Minerals (pp. 625-67). D. Reidel, Dordrecht. http://dx.doi.org/10.1007/978-94-009-4007-9_17

Tahir, R., \& Naseem, S. S. (2007). Removal of Cr(III) from tannery wastewater by adsorption onto bentonite clay. Separation and Purification Technology, 53, 312-321. http://dx.doi.org/10.1016/j.seppur.2006.08.008

Table 1. Physical Properties of Fly Ash

\begin{tabular}{|l|c|}
\hline Specific gravity & 2.03 \\
\hline Liquid Limit (\%) & 35 \\
\hline Plastic Limit (\%) & -- \\
\hline Plasticity Index (\%) & -- \\
\hline Shrinkage Limit (\%) & 18.5 \\
\hline \multicolumn{2}{|c|}{ Compaction Characteristics } \\
\hline Maximum dry density (kN/m ${ }^{3}$ ) & 11.7 \\
\hline Optimum moisture content (\%) & 25.0 \\
\hline \multicolumn{2}{|c|}{ Grain size distribution } \\
\hline Gravel (\%) & 00 \\
\hline Sand (\%) & 58 \\
\hline Silt and clay (\%) & 42 \\
\hline
\end{tabular}


Table 2. Chemical composition of fly ash

\begin{tabular}{|c|c|}
\hline Constituents & Percentage \\
\hline $\mathrm{SiO}_{2}$ & 61.10 \\
\hline $\mathrm{Al}_{2} \mathrm{O}_{3}$ & 28.00 \\
\hline $\mathrm{TiO}_{2}$ & 1.30 \\
\hline $\mathrm{Fe}_{2} \mathrm{O}_{3}$ & 4.20 \\
\hline $\mathrm{MgO}$ & 0.80 \\
\hline $\mathrm{CaO}$ & 1.7 \\
\hline $\mathrm{K}_{2} \mathrm{O}$ & 0.18 \\
\hline $\mathrm{Na}_{2} \mathrm{O}$ & 0.18 \\
\hline L.O.I & 1.40 \\
\hline
\end{tabular}

Table 3. Physical properties of bentonite

\begin{tabular}{|c|c|}
\hline Properties & Bentonite \\
\hline Specific gravity & 2.76 \\
\hline Liquid limit (\%) & 374 \\
\hline Plastic limit (\%) & 63 \\
\hline Plasticity index (PI)\% & 311 \\
\hline Sediment volume in water (ml/g) & 16 \\
\hline Max dry unit weight (kN/m ${ }^{3}$ ) & 11.7 \\
\hline Optimum moisture content (\%) & 45 \\
\hline Soil classification (ASTM D24487-unified Soil classification system & CH-Fat clay \\
\hline Percentage Clay fraction (\%) & $\mathbf{2}$ \\
\hline
\end{tabular}

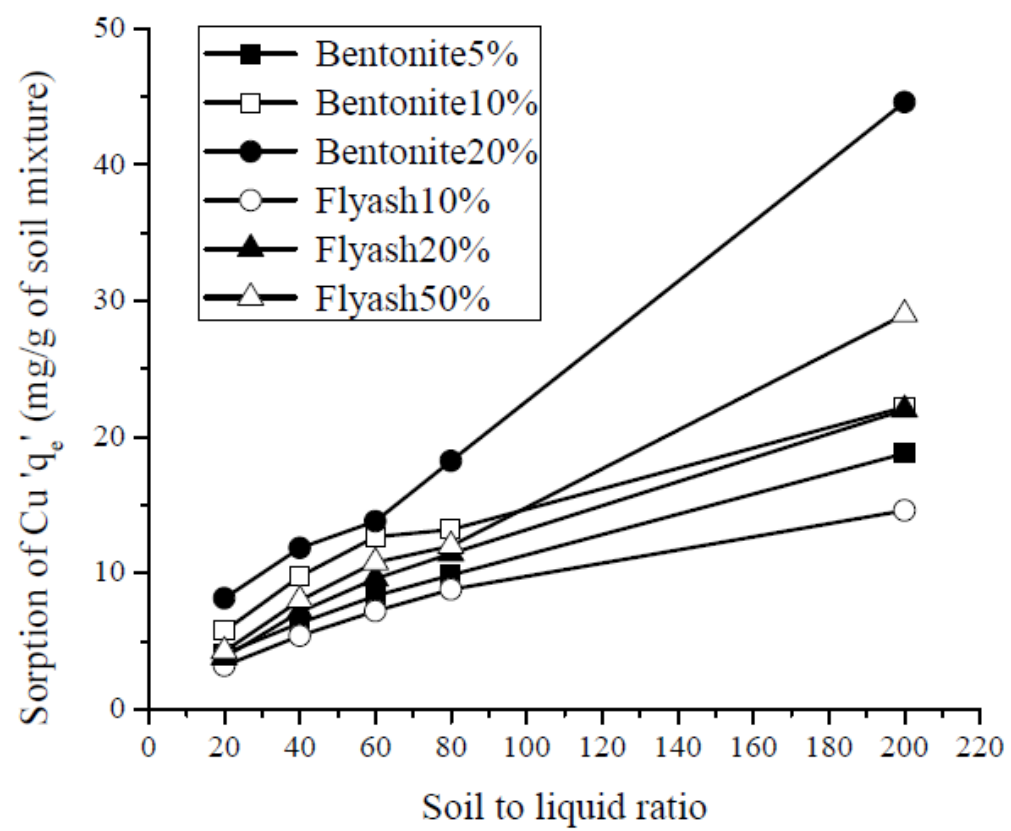

Figure 1. Adsorption of Copper by sand bentonite and sand fly ash mixtures. 


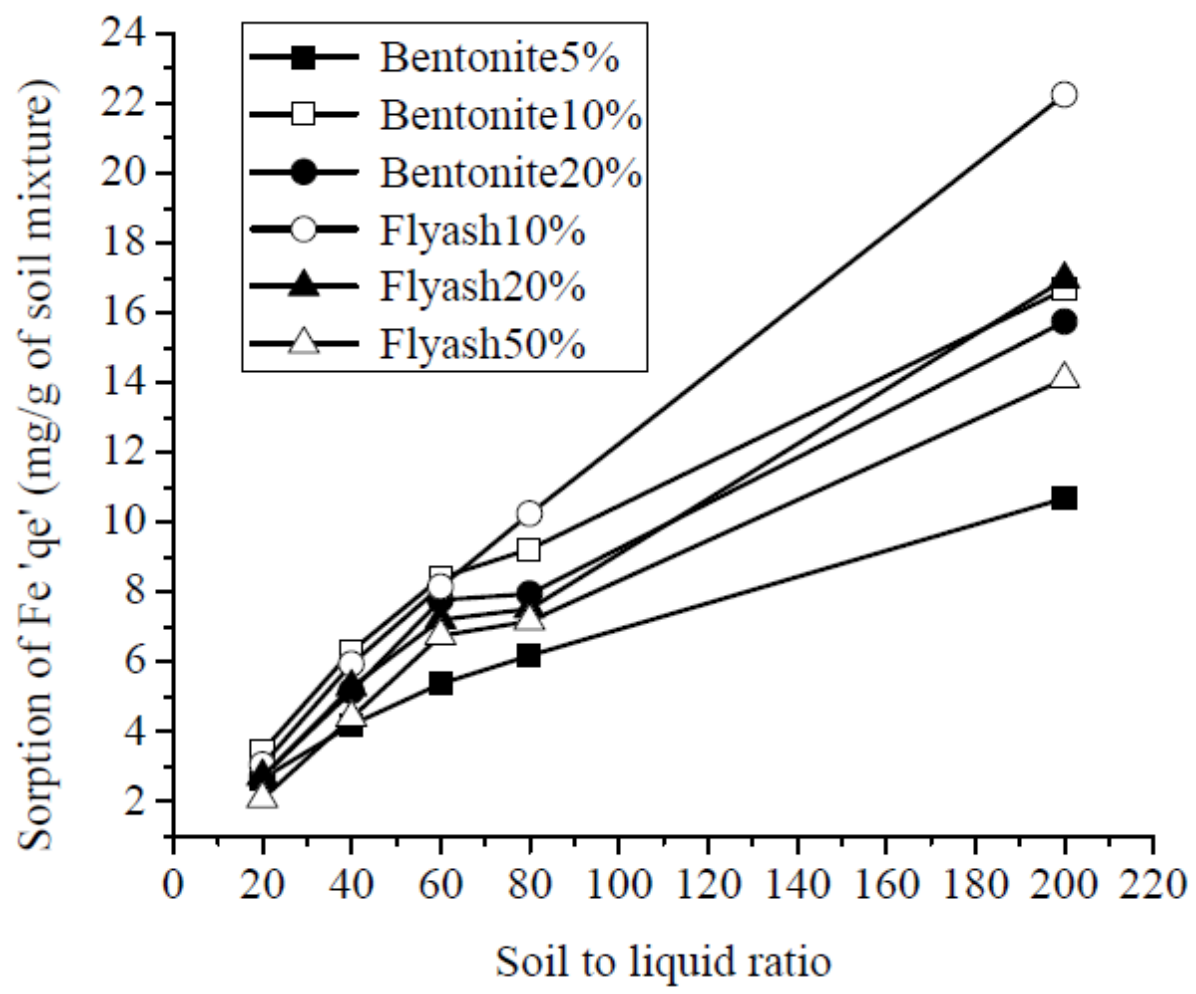

Figure 2. Adsorption of Iron by sand bentonite and sand fly ash mixtures

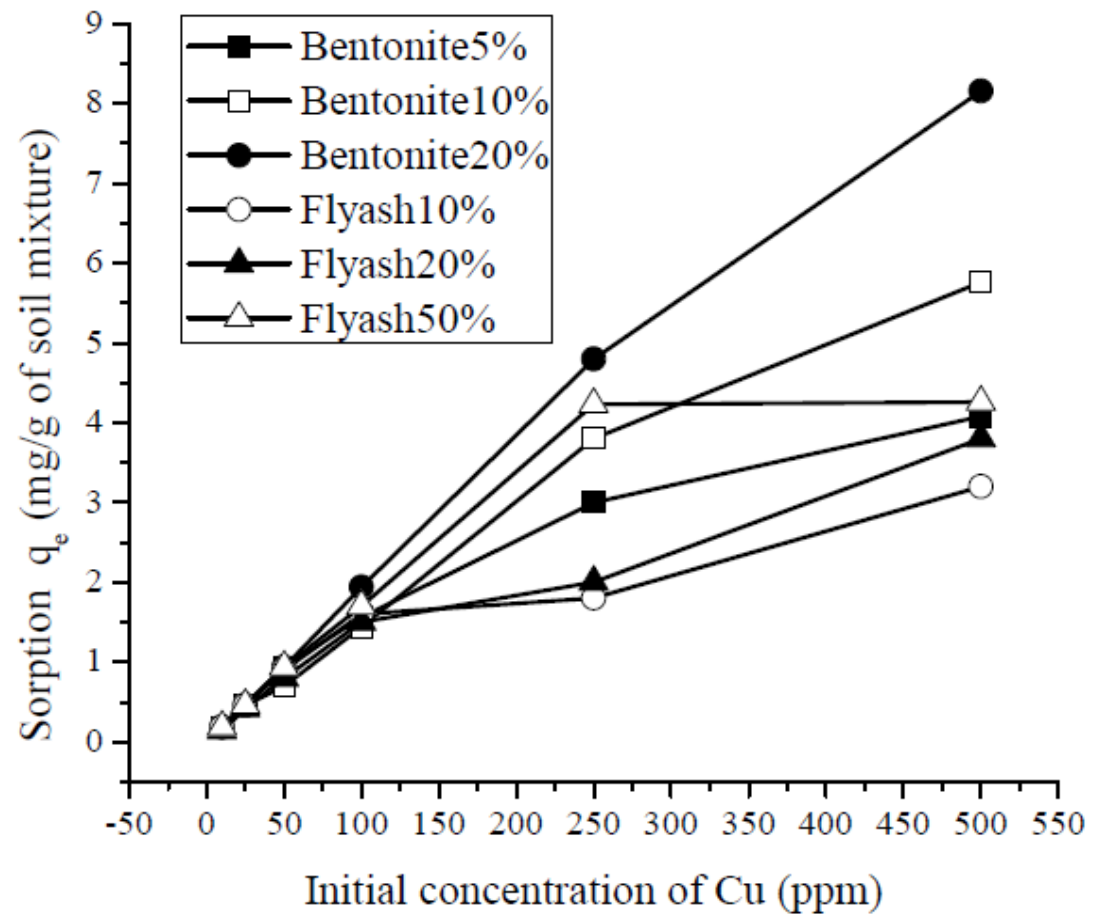

Figure 3. Adsorption of copper by sand bentonite and sand fly ash mixtures 


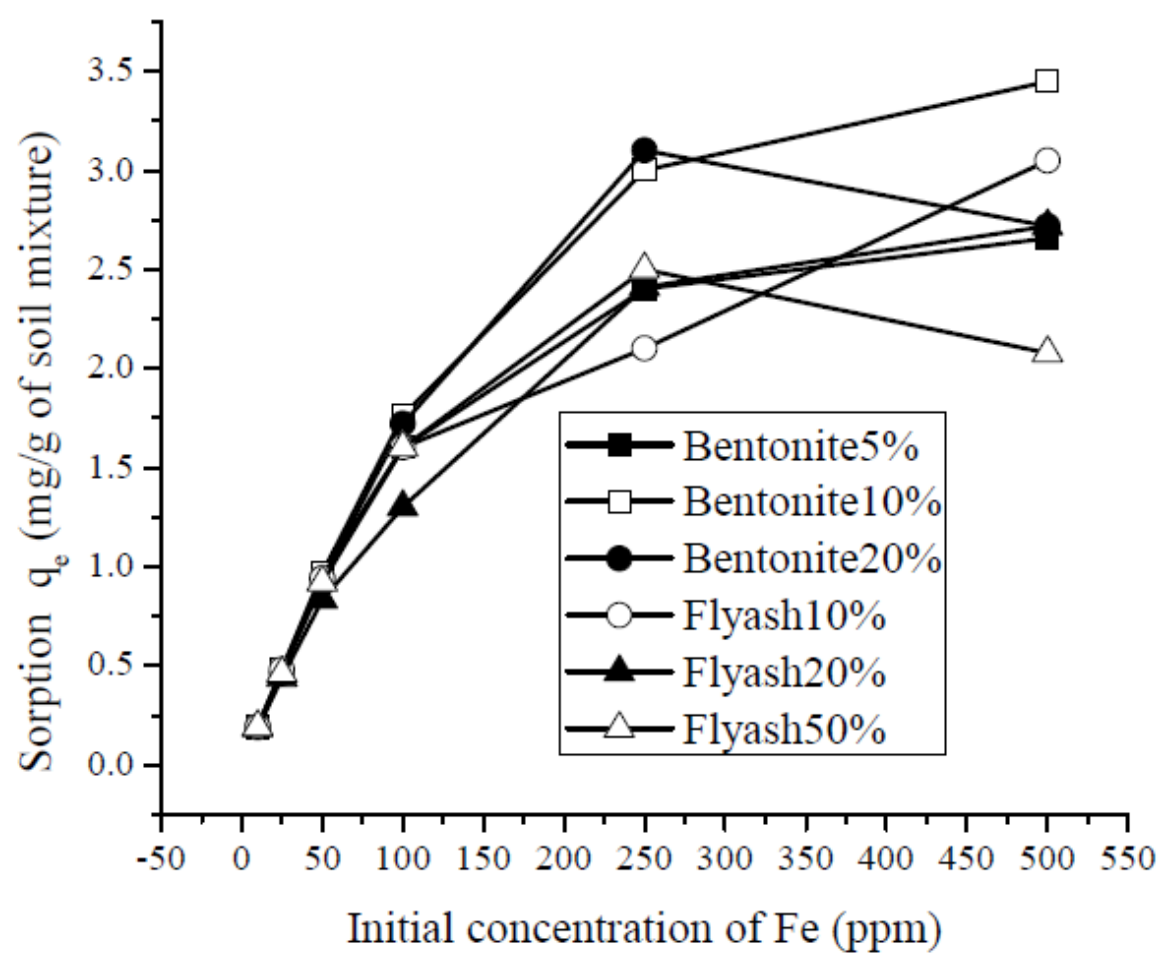

Figure 4. Adsorption of Iron by sand bentonite and sand fly ash mixtures

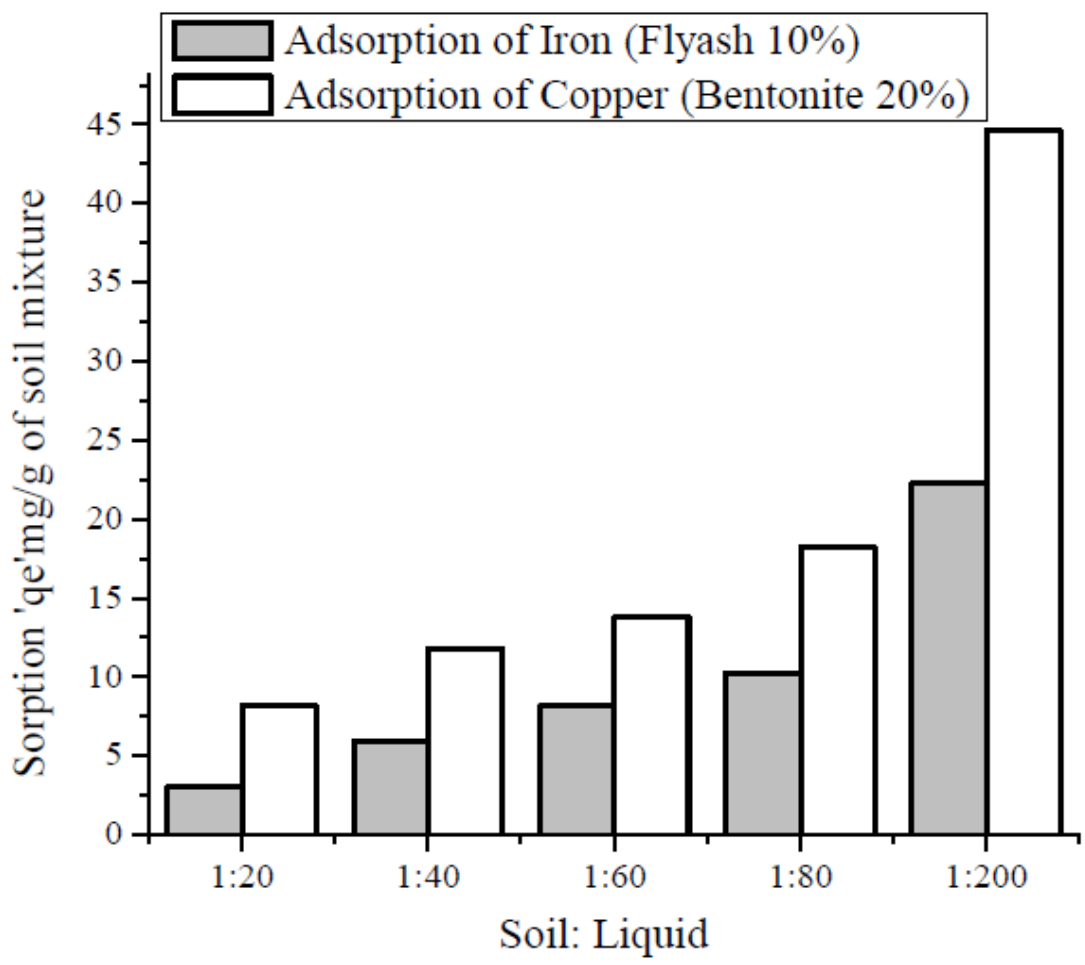

Figure 5. Comparison of iron and copper taking the mixtures which have given the highest sorption 


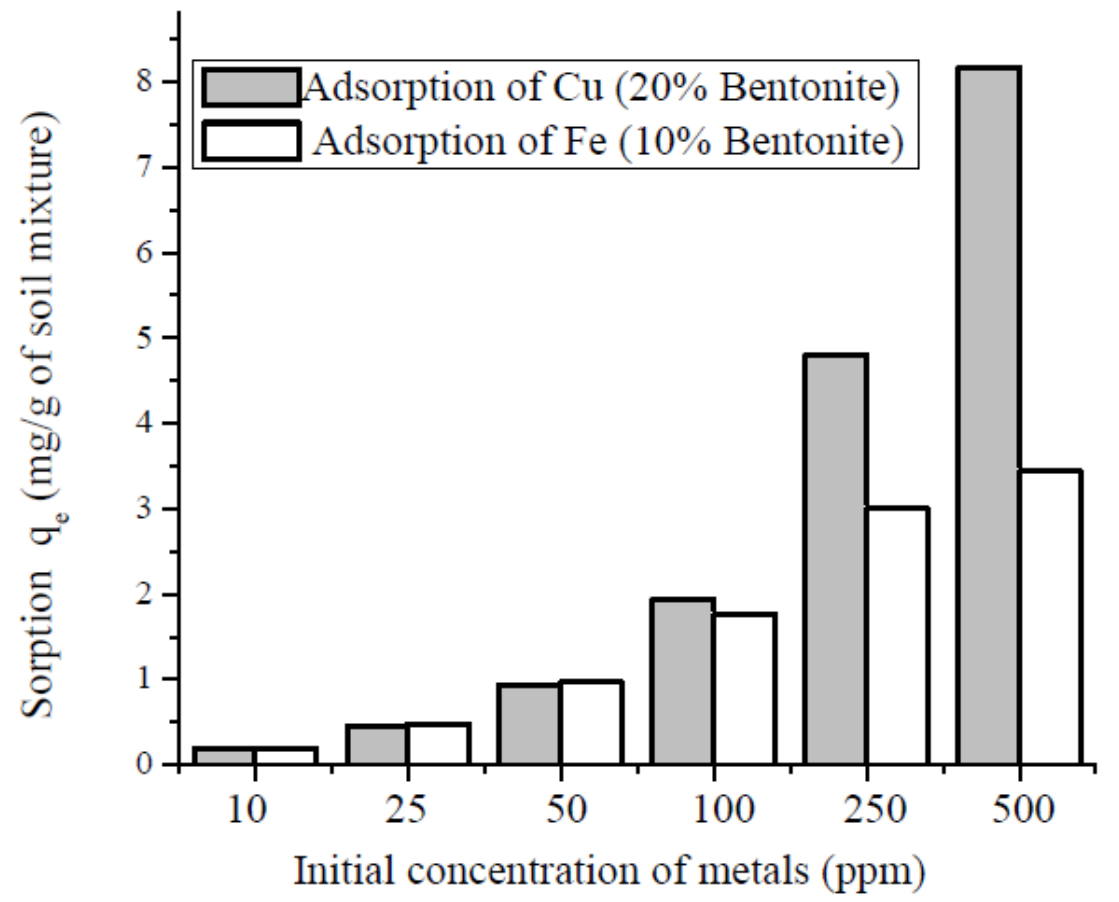

Figure 6. Comparison of iron and copper taking the mixtures which have given the highest sorption

\section{Copyright Disclaimer}

Copyright reserved by the author(s).

This article is an open-access article distributed under the terms and conditions of the Creative Commons Attribution license (http://creativecommons.org/licenses/by/3.0/). 